\title{
公衆浴場水の衛生学的研究
}

第 1 報 大阪市内公衆浴場浴水の実状

\author{
大阪市立衛生研究所 \\ 阪本茂。小竹正雄
}

\section{I 緒}

言

公衆浴場水の浴水の良否は公衆衛生上重要であり，こ れに関する調查成績122)334)5) もあるが，大阪市の比較的 多数の公㖣浴場の浴水調査の機会を得たので，その概要 を報告する。

大阪市内 892 件の公㖣浴場の内 82 件について昭和 28 年 9 月21日より10月20日まで 1 力月にわたり，その浴水の 細菌学的並びそ理化学的試験を実施した.

次飞市営公衆浴場22件飞ついて，11月4 日より11月11 日の間に同様の試験を行つた。

\section{II 調查方法並ひに調査項目}

19時より 21 時までが入浴人員最も多く，従つて污染度 最高となるので，採水時間をおおむね午後 8 時より 10 時 までの間とし，浴槽の中央部樑さ約 $30 \mathrm{~cm}$ のところで採 水し，翌朝まで冷蔵庫に入れ宦き試験を行つた。

調查項目は

理化学的試験 水温, 濁度, 色度, 反応, 塩素イオン, 過マンガン酸カリ消翼量, アンモニア,

細菌学的試験 $1 \mathrm{cc}$ 中の細菌集落数， $1 \mathrm{cc}$ 中の大腸 菌群最確数 (M.P.N)

尚水質の細菌学的, 理化学的検査方法は厚生省飲料水
衛生指針飞拠つた.

\section{III 調查成續並ひに考察}

1. 一般公鼻浴場（82件）

調査成績は附表 1 の通りである。

(1) 営業開始時間

営業開始時間は午前中のもの 2 件，他は午後 2 時よ り午後 3 時までであつた.

（2）湯の樑さ, 湯の量, 溢流の有無.

湯の深さは男女共最高 $1.1 \mathrm{~m}$ 最低 $0.7 \mathrm{~m}$ 平均 $0.91 \mathrm{~m}$ である。湯の量は男女共最高 $7.80 \mathrm{~m}^{3}$ 最低 $1.37 \mathrm{~m}^{3}$ 平均 $3.41 \sim 3.42 \mathrm{~m}^{3}$ である. 溢流している ものは男湯82件の内42件，女湯82件の内41件である.

(3) 採水時までの入浴人員

男湯の入浴者最高 700 人，最低 40 人，平均 151 人， 女湯の最高 700 人，最低 50 人，平均 186 人である.

（4）浴水の細菌学的並びそ理化学的性状.

調查成績を第 1 表に示した。

2. 市営公乑浴場

調查成續は附表 2 の通りである.

(1) 営業開始時間

営業開始時間恬午前中の屯の 2 件，他恬午後 2 時 30 分ないし 4 時で大多数は午後 3 時である.

第 1 表 一般公衆浴場の浴水 (82例)

\begin{tabular}{|c|c|c|c|c|c|c|c|c|c|c|}
\hline & & 温 度 & 濁 度 & 色 度 & 反俯 & $\begin{array}{c}\text { 塩素イオン } \\
\mathrm{mg} / \mathrm{lt}\end{array}$ & \begin{tabular}{|c|} 
過マソガン酸 \\
カリ消費量 \\
$\mathrm{mg} / \mathrm{lt}$
\end{tabular} & $\begin{array}{c}\text { アンモ }=> \\
\mathrm{mg} / \mathrm{lt}\end{array}$ & $\begin{array}{c}\text { 一般細菌/cc } \\
\text { (単位千) }\end{array}$ & $\begin{array}{l}\text { 大腸菌群/cc } \\
(\mathrm{M} . \mathrm{P} . \mathrm{N})\end{array}$ \\
\hline \multirow[t]{2}{*}{ 男 } & 最 高 & 47.0 & 15.0 & 12.0 & 7.4 & 62.5 & 23.28 & 1.30 & 21200 & 240 \\
\hline & 最 低 & 39.0 & 4.0 & 4.0 & 6.2 & 9.5 & 3. 32 & 0.14 & 2 & 0 \\
\hline 湯 & 平 均 & 43.3 & 8.7 & 6.6 & 6.6 & 16.40 & 11. 30 & 0.38 & 3806 & 20 \\
\hline \multirow[t]{2}{*}{ 女 } & 最 高 & 47.0 & 14.0 & 10.0 & 7.2 & 62.0 & 22.44 & 1.34 & 37600 & 240 \\
\hline & 最 低 & 41.0 & 4.5 & 4.0 & 6.3 & 10.0 & 5.21 & 0.17 & 22 & 0 \\
\hline 湯 & 平均 & 43.7 & 7.7 & 6.1 & 6.6 & 16.08 & 10.80 & 0.39 & 4148 & 23 \\
\hline
\end{tabular}

䃒考 単位…... 


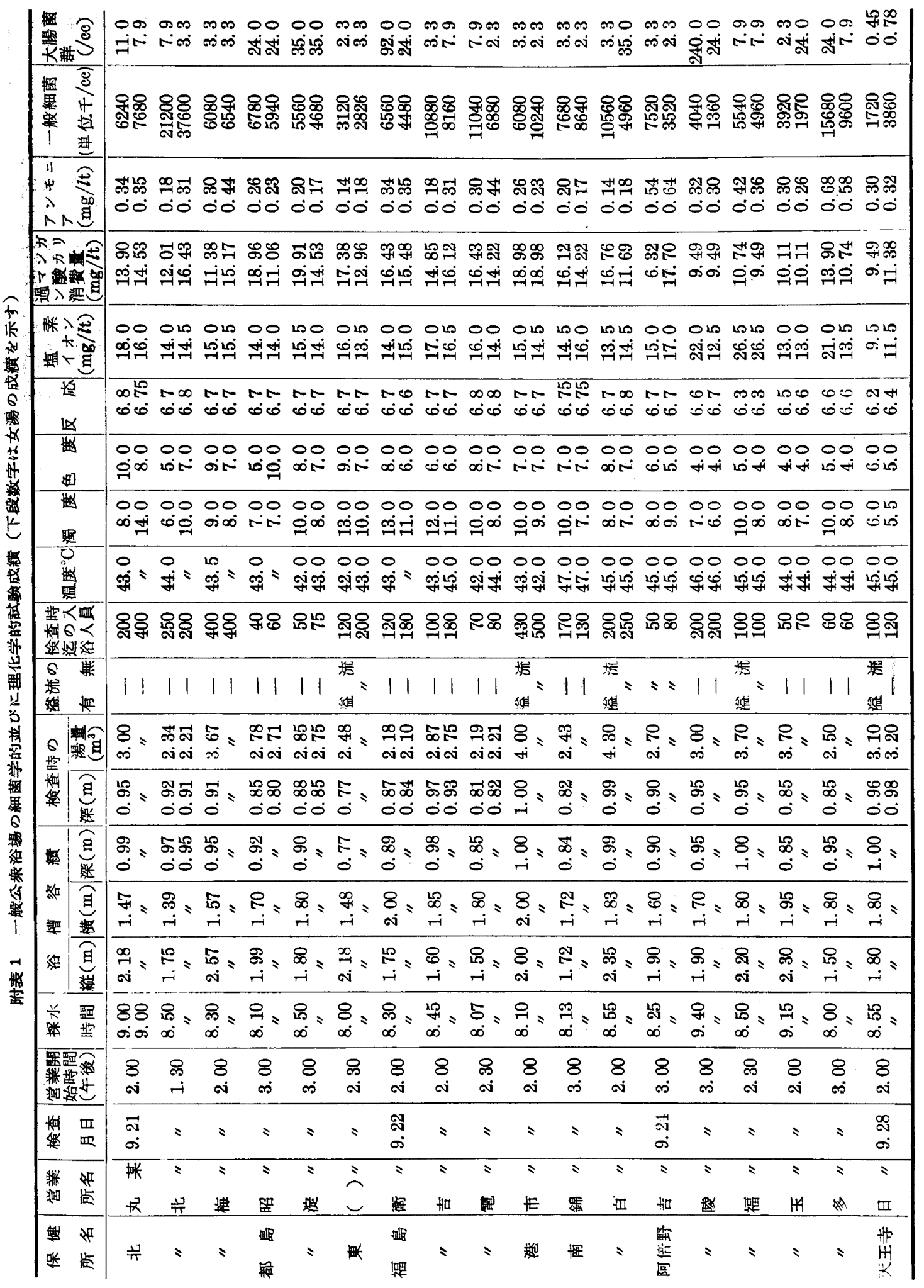




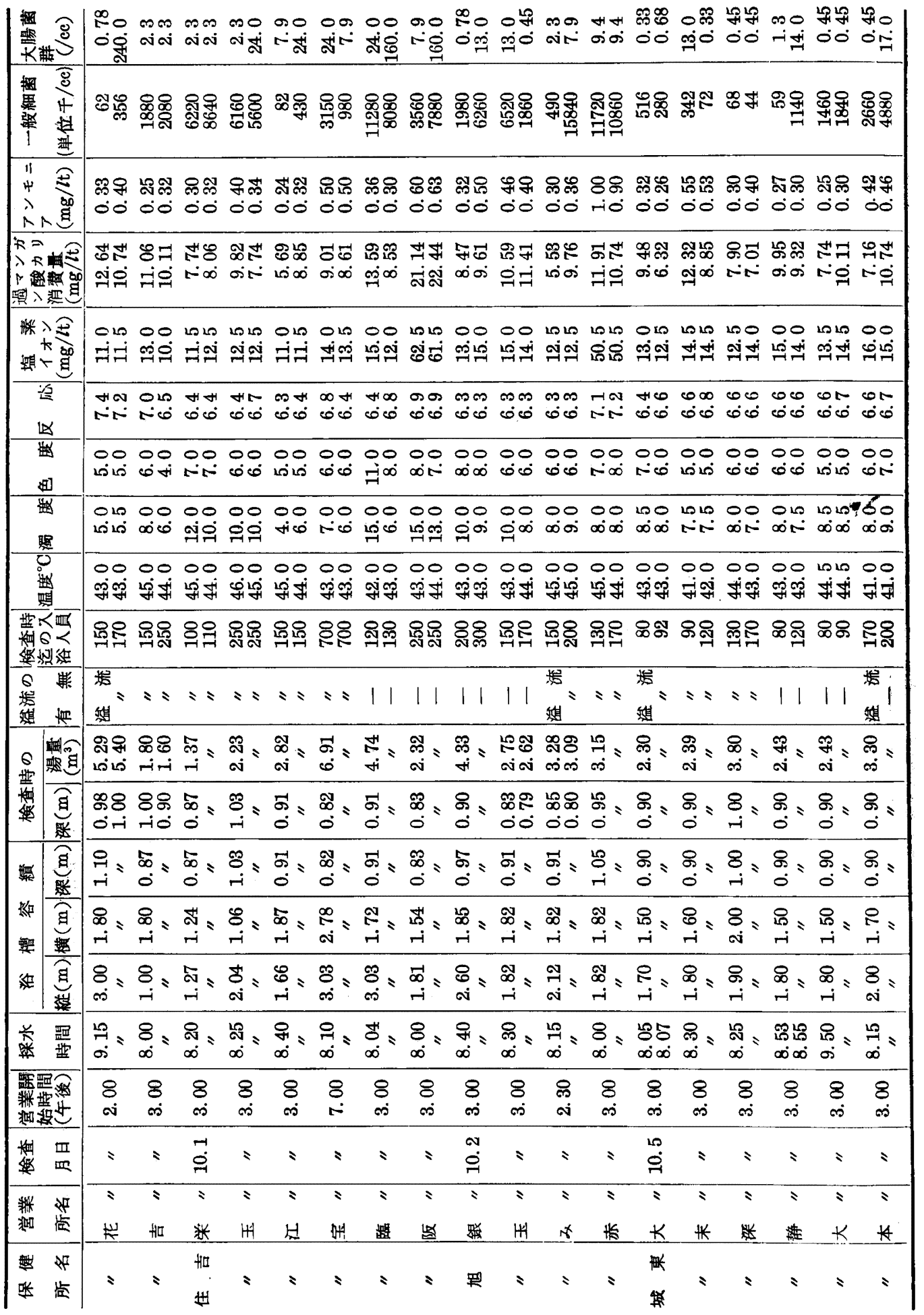




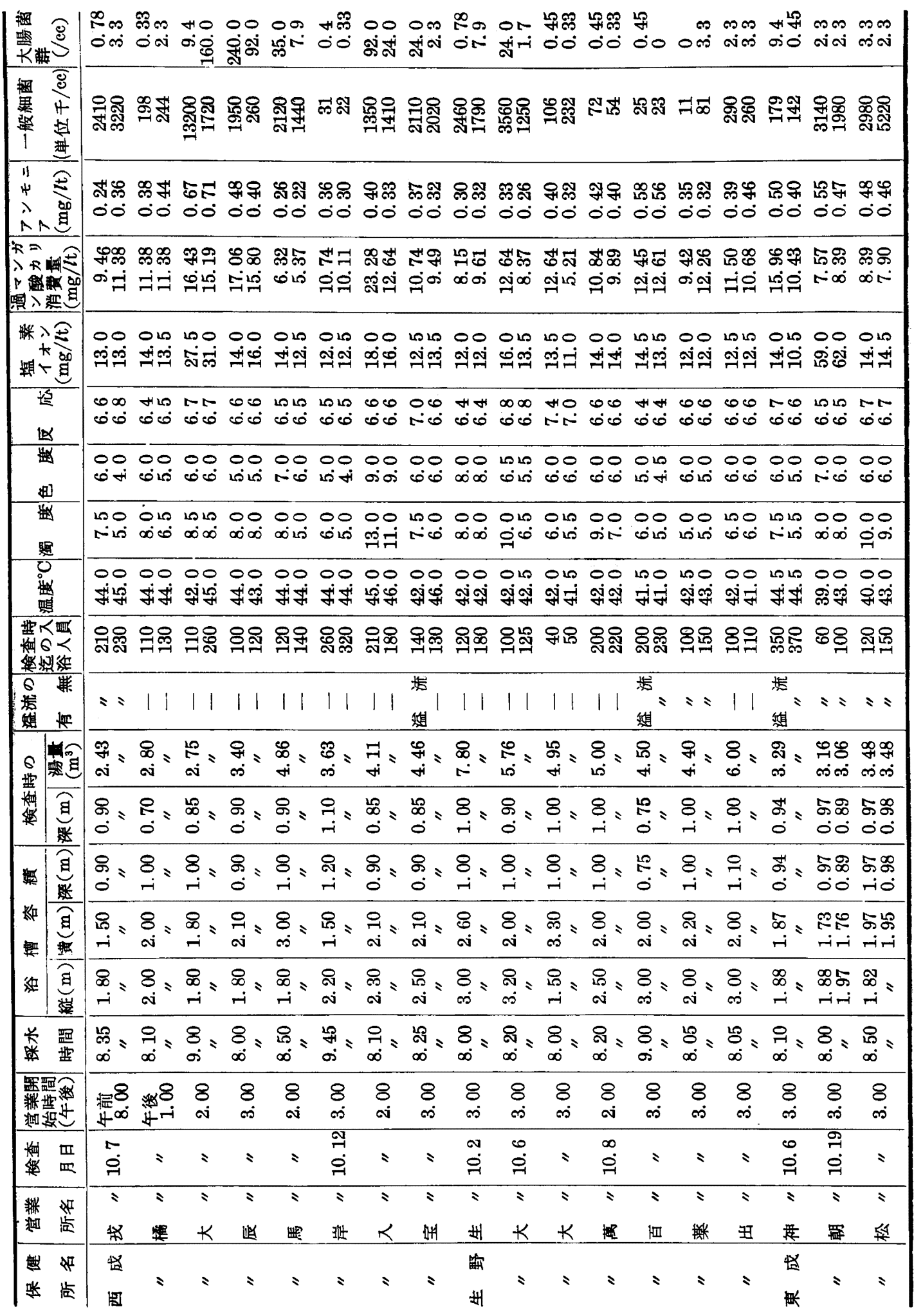




\begin{tabular}{|c|c|c|c|c|c|c|c|c|c|c|c|c|c|c|c|c|c|c|}
\hline 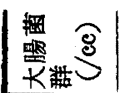 & $\begin{array}{l}\infty \infty \\
\infty \times \infty\end{array}$ & 00 & ơ & $\begin{array}{l}\infty \infty \\
00\end{array}$ & 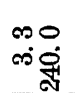 & అִ & 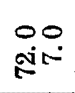 & $\begin{array}{l}\mathscr{m} \\
00\end{array}$ & or & $\stackrel{\infty}{\stackrel{\infty}{0}-1}$ & $\begin{array}{l}00 \\
\text { ți }\end{array}$ & تُ- & no & 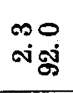 & 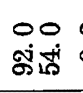 & $\begin{array}{l}\infty \infty \\
\text { min }\end{array}$ & 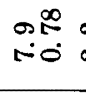 & 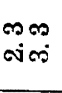 \\
\hline 秵 & 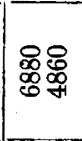 & เึสิ & 도윰 & ర్ర్లోన్లో & 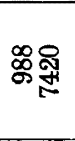 & 串융 & 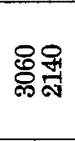 & 꾺욤 & న వ్యి & 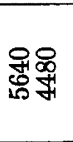 & 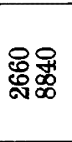 & శ్ำ & 急茫 & ๓ึㄱㅁㅈㅓ & 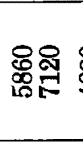 & 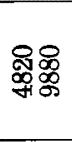 & స్ా윰 & 윆검 \\
\hline 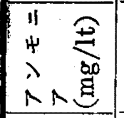 & $\begin{array}{l}\text { 出通 } \\
00\end{array}$ & $\begin{array}{l}\text { ł } \\
\text { ஸ0 } \\
\text { :0 }\end{array}$ & $\begin{array}{l}\text { क्ञ } \\
\text { :0 } \\
\text { :0 }\end{array}$ & $\begin{array}{l}\text { Lొ से } \\
00 \\
00\end{array}$ & 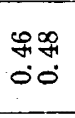 & 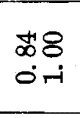 & 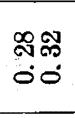 & $\begin{array}{l}\text { 赵 } \\
\text { ஸे }\end{array}$ & 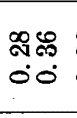 & $\begin{array}{l}\text { कొ } \\
00 \\
00\end{array}$ & $\begin{array}{l}\text { న๊en } \\
\text { 00 }\end{array}$ & 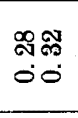 & $\begin{array}{l}\text { م्లి } \\
\text { ல0 }\end{array}$ & 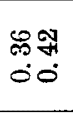 & $\begin{array}{l}\text { 品 } \\
\text { rif }\end{array}$ & $\begin{array}{l}\text { Lit } \\
00 \\
00\end{array}$ & $\begin{array}{l}\text { ๙ొ우 } \\
\text { 이 }\end{array}$ & 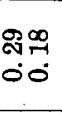 \\
\hline 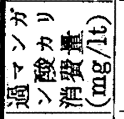 & $\begin{array}{l}\infty 10 \\
\infty \infty \\
\infty \\
\infty\end{array}$ & $\begin{array}{l}\text { 둥 } \\
\text { का }\end{array}$ & $\begin{array}{l}\text { क्ष } \\
\text { के }\end{array}$ & 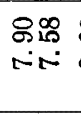 & 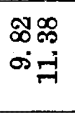 & 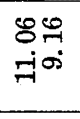 & $\begin{array}{l}810 \\
0 \%\end{array}$ & $\begin{array}{l}\text { gृ भ } \\
\text { क் }\end{array}$ & 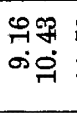 & 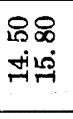 & 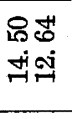 & 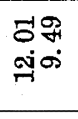 & 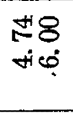 & 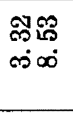 & 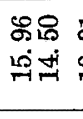 & 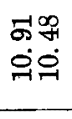 & $\begin{array}{l}S 5 \\
\sigma \omega\end{array}$ & 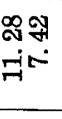 \\
\hline 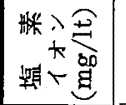 & $\begin{array}{l}100 \\
1200 \\
100\end{array}$ & 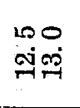 & $\begin{array}{l}00 \\
\text { सं }\end{array}$ & ما & مَ مان & $\begin{array}{l}00 \\
\infty \\
\text { जै }\end{array}$ & 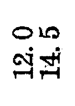 & $\begin{array}{l}\text { oิ } \\
\text { งิ่ง }\end{array}$ & مَ مَ مَ & $\begin{array}{l}0 \\
00 \\
0 \\
0\end{array}$ & مان & 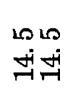 & $\begin{array}{l}1020 \\
\text { નંْึ่ }\end{array}$ & 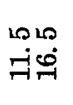 & $\begin{array}{l}00 \\
\text { क्ञનं }\end{array}$ & $\begin{array}{l}010 \\
1200 \\
-101\end{array}$ & $\begin{array}{l}120 \\
0909\end{array}$ & 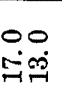 \\
\hline $\mathbb{Q}$ & $\begin{array}{l}00 \\
\dot{0} 0\end{array}$ & $\overrightarrow{0}$ & $\begin{array}{l}00 \\
00\end{array}$ & 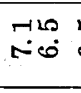 & $\begin{array}{l}100 \\
000\end{array}$ & $\begin{array}{l}0 \% \\
60\end{array}$ & $\begin{array}{l}00 \\
\oplus 0\end{array}$ & $\begin{array}{l}0 \pi \\
00\end{array}$ & $\begin{array}{l}00 \\
00 \\
00\end{array}$ & $\begin{array}{l}00 \\
00\end{array}$ & $\begin{array}{l}00 \\
60\end{array}$ & $\begin{array}{l}105 \\
60\end{array}$ & $\begin{array}{l}\infty 100 \\
000\end{array}$ & $\begin{array}{l}00 \\
000\end{array}$ & $\begin{array}{l}00 \\
60\end{array}$ & $\begin{array}{l}0.00 \\
00\end{array}$ & $\overrightarrow{0} 0$ & $\begin{array}{l}01 \\
00\end{array}$ \\
\hline 粠 & $\begin{array}{l}00 \\
00\end{array}$ & $\begin{array}{l}00 \\
\text { मீ. }\end{array}$ & $\begin{array}{l}00 \\
0.10\end{array}$ & $\begin{array}{l}00 \\
\text { L }\end{array}$ & مانب & $\begin{array}{l}00 \\
0010\end{array}$ & $\begin{array}{l}00 \\
00\end{array}$ & $\begin{array}{l}00 \\
100\end{array}$ & $\begin{array}{l}00 \\
\text { เค }\end{array}$ & $\begin{array}{l}100 \\
\infty 0^{\circ}\end{array}$ & $\begin{array}{l}00 \\
\infty \infty \\
\infty\end{array}$ & $\begin{array}{l}00 \\
00\end{array}$ & $\begin{array}{l}00 \\
100\end{array}$ & $\begin{array}{l}00 \\
-0\end{array}$ & $\begin{array}{l}\text { 음 } \\
\text { ง่ํ욤 }\end{array}$ & $\begin{array}{l}00 \\
\text { oit }\end{array}$ & $\begin{array}{l}00 \\
\text { कie }\end{array}$ & $\begin{array}{l}00 \\
\text { Sit }\end{array}$ \\
\hline 衅 & $\begin{array}{l}00 \\
00\end{array}$ & $\begin{array}{l}00 \\
10^{\circ} 10^{\circ}\end{array}$ & $\begin{array}{l}00 \\
000\end{array}$ & $\begin{array}{l}010 \\
010 \\
010\end{array}$ & $\begin{array}{l}00 \\
\infty 0\end{array}$ & $\begin{array}{l}010 \\
010\end{array}$ & $\begin{array}{l}0.20 \\
1000\end{array}$ & $\begin{array}{l}100 \\
10^{\circ} 20^{\circ}\end{array}$ & $\begin{array}{l}010 \\
1074\end{array}$ & 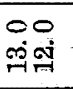 & $\begin{array}{l}00 \\
\text { 위유. }\end{array}$ & $\begin{array}{l}00 \\
500\end{array}$ & $\begin{array}{l}00 \\
100\end{array}$ & $\begin{array}{l}00 \\
\therefore 0\end{array}$ & $\begin{array}{l}\text { OO } \\
\text { सేझ़త }\end{array}$ & $\begin{array}{l}00 \\
m \rightarrow-1\end{array}$ & $\begin{array}{l}\text { oo } \\
\text { Nit }\end{array}$ & $\begin{array}{l}00 \\
\text { Jio }\end{array}$ \\
\hline 愣 & $\begin{array}{l}00 \\
\log 20 \\
41\end{array}$ & $\begin{array}{l}\text { ○ิ } \\
\text { ช่จุ์ }\end{array}$ & $\begin{array}{l}00 \\
\text { เอ่ }\end{array}$ & $\begin{array}{l}\text { ○๐ } \\
\text { ม่ ม่ }\end{array}$ & $\begin{array}{l}\text { ○๐ } \\
\text { ม่ง }\end{array}$ & $\begin{array}{l}00 \\
\text { พั่ }\end{array}$ & $\begin{array}{l}00 \\
\text { تु่ }\end{array}$ & $\begin{array}{l}00 \\
\text { Jis }\end{array}$ & $\begin{array}{l}\circ 0 \\
\text { พ่ษ }\end{array}$ & $\begin{array}{l}00 \\
\text { अंष्ष }\end{array}$ & $\begin{array}{l}100 \\
\forall-99\end{array}$ & $\begin{array}{l}00 \\
\text { เุ่ }\end{array}$ & $\begin{array}{l}00 \\
\text { किंक }\end{array}$ & $\begin{array}{l}00 \\
\text { अंष्म }\end{array}$ & $\begin{array}{l}00 \\
\text { jं }\end{array}$ & $\begin{array}{l}00 \\
\dot{H}+4\end{array}$ & $\begin{array}{l}00 \\
\text { Lึं }\end{array}$ & $\begin{array}{l}00 \\
\text { की }\end{array}$ \\
\hline 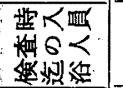 & 은욤 & ి్రత్తి & 옥용 & 요 & ్ㅠㅇㅠ & ర్ㄱㅇㅛ & ర్తిథ్లి & 육윰 & 요음 & 웜요 & 丞 & ํํㅇㅇㅛ & 오유 & ్్ㅁㅇㅠ & 욤유 & ్ㅗ욤 & 윰역 & 윰윰 \\
\hline 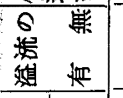 & $s=$ & $=s$ & 11 & 11 & 11 & 治 & 1 & 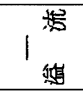 & $=$ : & $=1$ & 倠 & 11 & & $=$ & $\Sigma:$ & $=\Sigma$ & $=$ & 11 \\
\hline 6 & $\begin{array}{l}n \\
\infty \\
\infty \\
\infty\end{array}$ & ${ }_{\infty}^{\infty}=$ & $\begin{array}{l}\infty \\
\infty\end{array}$ & $\begin{array}{l}m= \\
\dot{m}\end{array}$ & $\stackrel{10}{m}=$ & 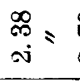 & $\begin{array}{l}\text { P. } \\
\text { mं }\end{array}$ & $\begin{array}{l}\text { ๓⿴囗十 } \\
\text { ๓ं }\end{array}$ & กิ & $\begin{array}{l}\text { ED } \\
\text { in }\end{array}$ & $\begin{array}{l}\text { Rit } \\
\text { git }\end{array}$ & $\begin{array}{l}\mathscr{P} \infty \\
\infty \\
100 \\
10\end{array}$ & $\begin{array}{l}188 \\
\infty 8+1\end{array}$ & $\begin{array}{l}\infty \\
\infty \\
\infty \\
\infty\end{array}$ & $\underset{\sim}{\mathbb{m}}=$ & $\begin{array}{l}\infty \\
\infty \\
\dot{\omega}\end{array}$ & $\begin{array}{l}g \\
\dot{q}\end{array}$ & $\begin{array}{l}\text { Nop } \\
\text { n் n }\end{array}$ \\
\hline 智 造 & $\begin{array}{l}\text { ळ\% } \\
\text { ஸ் }\end{array}$ & $\begin{array}{l}10 \\
0 \\
0\end{array}$ & $\begin{array}{l}\infty \\
\infty \\
0\end{array}=$ & $\begin{array}{l}\infty \\
\infty \\
0\end{array}$ & $\begin{array}{l}\infty \\
\infty \\
0\end{array}$ & $\begin{array}{l}\vec{\sigma} \\
\dot{0}\end{array}$ & $\begin{array}{l}\infty 08 \\
00\end{array}$ & $\begin{array}{l}8 \% \\
0 \%\end{array}$ & $\begin{array}{l}\sigma \\
0\end{array}$ & $\begin{array}{l}\qquad 88 \\
\circ 8 \\
00 \\
\end{array}$ & $\begin{array}{l}\angle 8 \% \\
00\end{array}$ & $\begin{array}{l}\text { Sా } \\
\dot{0} 0\end{array}$ & $\begin{array}{l}\mathscr{8} \\
\infty 0 \\
00\end{array}$ & $8:$ & $8=$ & $\begin{array}{l}+1 \\
0 \\
0\end{array}$ & $\stackrel{8}{\tilde{B}}=8$ & $\begin{array}{l}\text { हैं } \\
\text { ல் }\end{array}$ \\
\hline 点 & $\begin{array}{l}18 \% \\
50 \\
00\end{array}$ & $\begin{array}{l}18 \\
0\end{array}$ & $5:$ & $8=$ & $\begin{array}{l}8 \\
0\end{array}$ & $\begin{array}{l}\dot{\sigma} \\
\dot{0}\end{array}$ & $\begin{array}{l}\sigma \\
0\end{array}$ & $\stackrel{\mathscr{O}}{\circ}=$ & $\begin{array}{l}\dot{\theta} \\
\dot{0}\end{array}$ & $\stackrel{\leftrightarrow}{\circ}=$ & $\stackrel{20}{\circ}=$ & 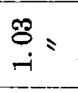 & $\begin{array}{l}8 \\
0\end{array}$ & $\begin{array}{l}8 \\
i\end{array}$ & $\begin{array}{l}8 \\
\sigma\end{array}=$ & $\begin{array}{l}-1 \\
0 \\
0\end{array}$ & $\stackrel{\mathscr{g}}{\dot{r}}=$ & $\begin{array}{l}\mathscr{8}:= \\
\dot{0}:\end{array}$ \\
\hline 望 & $\begin{array}{l}\text { 요 } \\
\text { rif }\end{array}$ & $\stackrel{\infty}{\infty}=$ & is & $\mathscr{8}=$ & $\begin{array}{l}9 \\
9 \\
-1\end{array}$ & $\ddot{H}=$ & $\underset{*}{\mathscr{P}}=$ & $\begin{array}{l}8 \\
\text { i }\end{array}$ & $\underset{\infty}{\infty}=$ & $\begin{array}{l}8 \\
\text { i }\end{array}$ & $\begin{array}{l}\infty \\
\text { oi }\end{array}$ & รా & $8:$ & $\begin{array}{l}\infty \\
i\end{array}$ & $\begin{array}{l}\infty \\
-1\end{array}$ & $\begin{array}{l}\infty \\
\infty \\
\dot{r}\end{array}$ & $\underset{r}{\infty}=$ & ${ }_{i j}^{28}=$ \\
\hline 㤩 & $\begin{array}{l}\text { ఖळ } \\
\text { ri } \\
\end{array}$ & $\begin{array}{l}\text { लి } \\
\text { oi }\end{array}$ & $\frac{10}{20}=$ & 둥: & $\frac{\pi}{\sigma}=$ & $\%=$ & $\underset{\sim}{\stackrel{m}{a}}=$ & $\stackrel{\infty}{\infty}=$ & 㝵 $=$ & $\stackrel{8}{\circ}=$ & $\underset{-1}{\infty}=$ & $\stackrel{0}{\infty}=$ & $\begin{array}{l}\infty \\
\infty\end{array}$ & $\stackrel{8}{i}$ & $\begin{array}{l}\text { \& } \\
\text { Ni }\end{array}=$ & 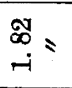 & $\underset{\text { ơ }}{\stackrel{\sim}{*}}=\stackrel{E}{r}$ & Fi \\
\hline 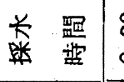 & $\underset{\infty}{\infty}=$ & $\stackrel{\infty}{\infty}=$ & $\begin{array}{l}8 \\
\infty\end{array}=$ & $\underset{\infty}{\stackrel{10}{10}}=$ & 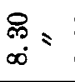 & $\underset{\infty}{\infty}=$ & $\begin{array}{l}\infty \\
\infty \\
\infty\end{array}$ & $\frac{8}{\infty}=$ & న $=$ & $\underset{\infty}{\stackrel{0}{1}}=$ & $\underset{\infty}{8}=$ & $\underset{\infty}{\infty}=$ & $\underset{\infty}{8}=$ & $\stackrel{10}{\infty}=$ & $\underset{+}{\infty} \leqslant$ & $\underset{\infty}{\stackrel{9}{0}}=$ & $\begin{array}{l}\stackrel{\circ}{\infty}=\stackrel{c}{\infty} \\
\infty\end{array}$ & $\begin{array}{l}\text { 尺ิ : } \\
\infty\end{array}$ \\
\hline 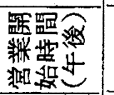 & $\begin{array}{l}8 \\
8\end{array}$ & $\begin{array}{l}\text { ㅇ } \\
\text { oi }\end{array}$ & $\begin{array}{l}8 \\
\infty\end{array}$ & $\begin{array}{l}8 \\
\text { क }\end{array}$ & $\begin{array}{l}8 \\
8\end{array}$ & $\begin{array}{l}8 \\
\text { ஸे }\end{array}$ & $\begin{array}{l}\text { \% } \\
\text { oi }\end{array}$ & $\begin{array}{l}8 \\
8\end{array}$ & $\underset{8}{8}$ & $\begin{array}{l}8 \\
\dot{\infty}\end{array}$ & $\begin{array}{l}8 \\
\text { is }\end{array}$ & $\begin{array}{l}8 \\
\text { i }\end{array}$ & $\begin{array}{l}\text { คి } \\
\text { งi }\end{array}$ & $\begin{array}{l}8 \\
\text { งi }\end{array}$ & $\begin{array}{l}\text { की } \\
\text { งi }\end{array}$ & ๙ & $\begin{array}{l}\text { \% } \\
\text { ง }\end{array}$ & $\begin{array}{l}8 \\
\text { i }\end{array}$ \\
\hline 筷留 & s & $=$ & $\dot{0}$ & $s$ & $\Sigma$ & $=$ & $\Sigma$ & 产 & $\Sigma$ & s & s & $\begin{array}{l}\stackrel{m}{\rightarrow-1} \\
\dot{0}\end{array}$ & $\Sigma$ & $=$ & $\Sigma$ & $\stackrel{10}{\stackrel{10}{9}}$ & s & $\leqslant$ \\
\hline \multirow[t]{2}{*}{$\begin{array}{l}\text { 秤 } \\
\text { 㴹吅 }\end{array}$} & $s$ & s & $=$ & $\Sigma$ & : & s & $\Sigma$ & $\Sigma$ & : & $\Sigma$ & $\Sigma$ & $\Sigma$ & $\Sigma$ & $=$ & $s$ & $=$ & s & $\Sigma$ \\
\hline & $\because$ & 盂 & 绩 & $K$ & W & $\leftarrow$ & is & 俩 & 呚 & 腊 & 惯 & 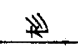 & $\because$ & 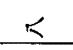 & ftin & 111 & 导 & 就 \\
\hline 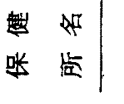 & $=$ & $=$ & 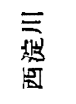 & $=$ & s & 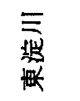 & $=$ & $s$ & s & $\Sigma$ & $\Sigma$ & 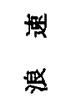 & s & 梤 & $\Sigma$ & 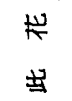 & s & 选 \\
\hline
\end{tabular}




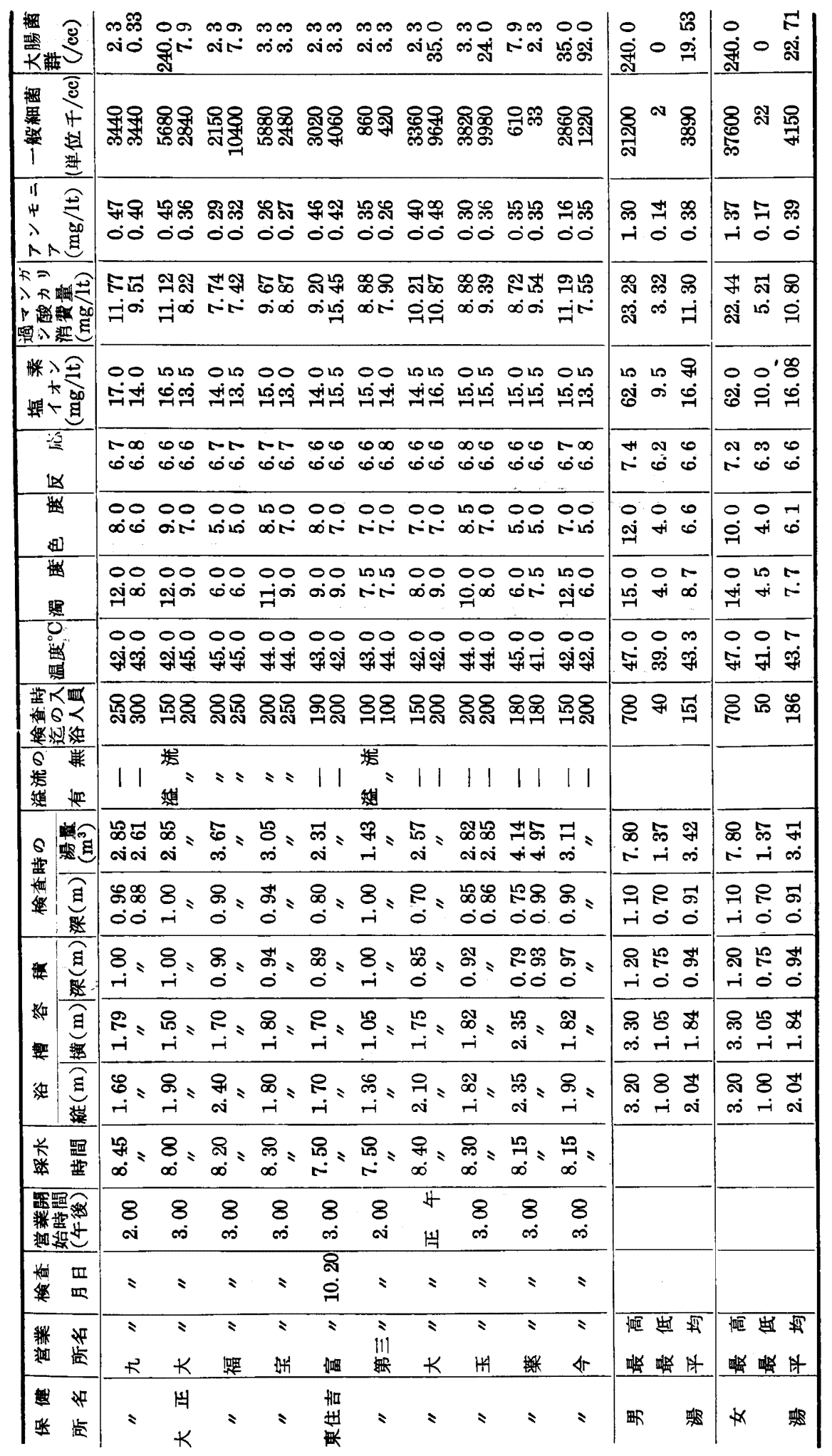




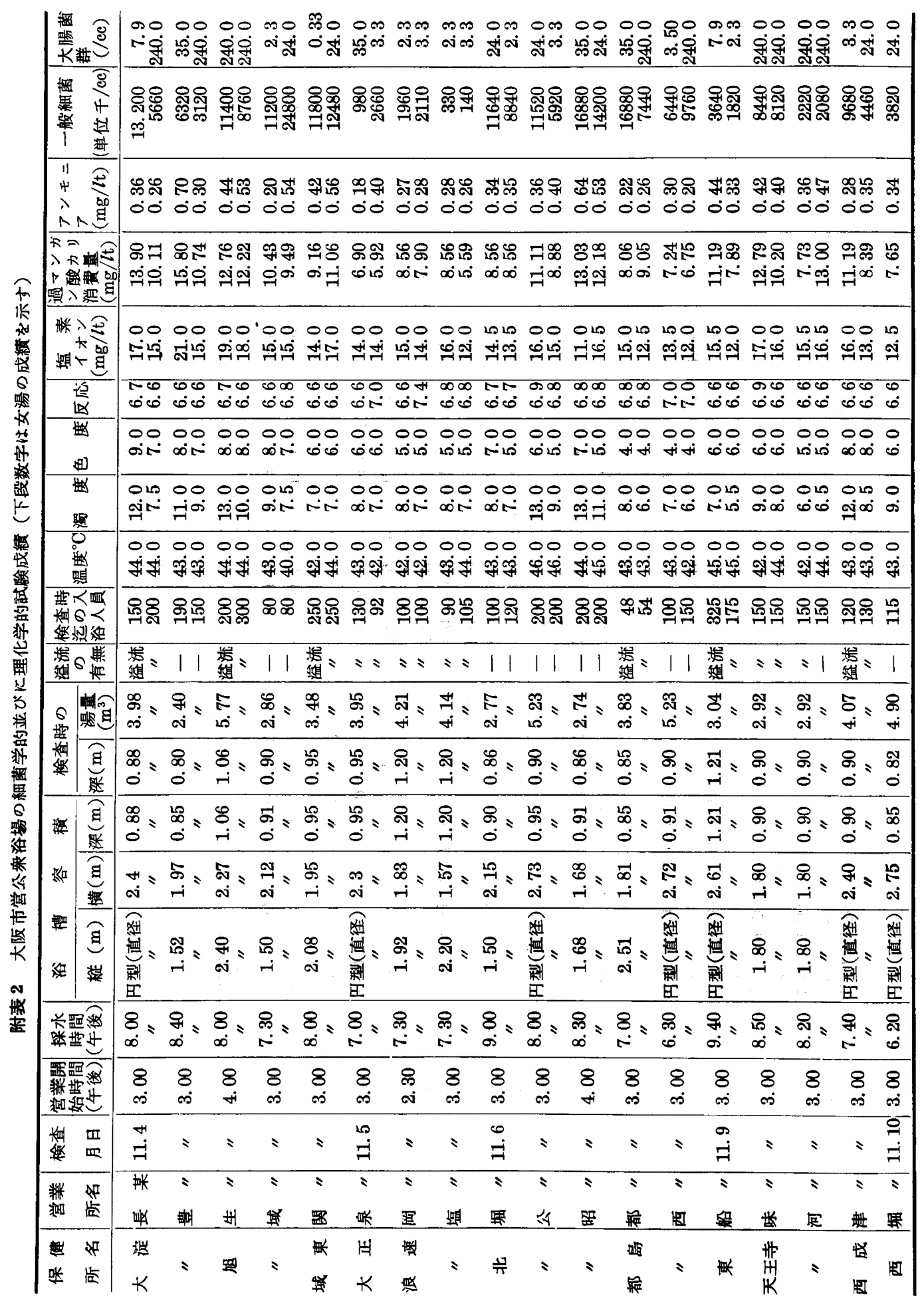




\begin{tabular}{|c|c|c|c|c|c|c|c|}
\hline 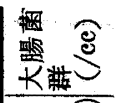 & 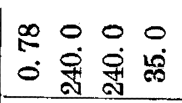 & 역 & $\begin{array}{l}\text { शू } \\
0\end{array}$ & $\begin{array}{l}0 \\
\infty \\
0\end{array}$ & 辠 & 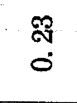 & 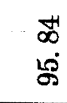 \\
\hline 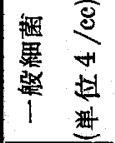 & 然 웡 \& & $\begin{array}{l}\mathbb{8} \\
: 0 \\
0 \\
0\end{array}$ & 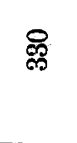 & $\begin{array}{l}? \\
2 \\
2\end{array}$ & $\begin{array}{l}8 \\
\stackrel{8}{8} \\
\text { d }\end{array}$ & 역 & 蛋 \\
\hline 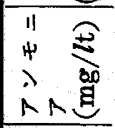 & $\begin{array}{llll}\pi & \& & 8 & H \\
0 & 0 & 0 & 0\end{array}$ & 芯 & $\stackrel{?}{\circ}$ & $\stackrel{\infty}{\sim}$ & 옹 & $\begin{array}{l}\infty \\
\stackrel{\infty}{0}\end{array}$ & ণి \\
\hline 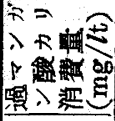 & 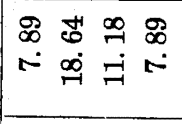 & $\begin{array}{l}\ddot{6} \\
\stackrel{-}{\rightarrow}\end{array}$ & $\begin{array}{l}8 \\
6 \\
0\end{array}$ & $\begin{array}{l}\mathscr{H} \\
\stackrel{9}{1}\end{array}$ & $\begin{array}{l}\mathscr{8} \\
\ddot{-1}\end{array}$ & $\begin{array}{l}80 \\
10 \\
10\end{array}$ & $\begin{array}{l}8 \\
0\end{array}$ \\
\hline 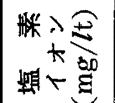 & 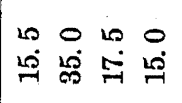 & 임 & $\stackrel{\circ}{-1}$ & $\begin{array}{l}\stackrel{\oplus}{\circ} \\
\stackrel{्}{\oplus}\end{array}$ & $\begin{array}{l}0 \\
\infty \\
\dot{q}\end{array}$ & $\begin{array}{l}0 \\
\stackrel{\sim}{u}\end{array}$ & $\begin{array}{l}5 \\
0 \\
0\end{array}$ \\
\hline 故 & $\begin{array}{llll}0 & 0 & 0 & 0 \\
0 & 0 & 0 & 0 \\
0 & 0 & 0 & 0 \\
\end{array}$ & $\begin{array}{l}0 \\
\therefore\end{array}$ & $\begin{array}{l}0 \\
6\end{array}$ & 5 & $\stackrel{4}{2}$ & $\begin{array}{l}0 \\
0\end{array}$ & 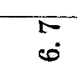 \\
\hline 进 & $\begin{array}{cccc}0 & 0 & 0 & 0 \\
\text { Lे } & 0 & \dot{0} & 0\end{array}$ & $\stackrel{\circ}{\circ}$ & $\stackrel{\circ}{+}$ & $\begin{array}{l}0 \\
0 \\
0 \\
0\end{array}$ & $\ddot{0}$ & + & $\begin{array}{l}7 \\
6\end{array}$ \\
\hline 题 & 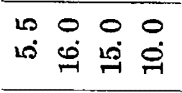 & $\begin{array}{l}\circ \\
\ddot{9}\end{array}$ & 100 & $\begin{array}{l}20 \\
\infty\end{array}$ & $\begin{array}{l}0 \\
\dot{H}\end{array}$ & L & $\begin{array}{c}5 \\
5\end{array}$ \\
\hline 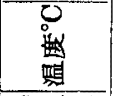 & 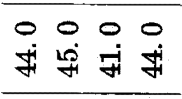 & $\begin{array}{l}\circ \\
\dot{9}\end{array}$ & $\begin{array}{l}0 \\
\dot{j}\end{array}$ & $\begin{array}{l}\infty \\
\dddot{F}\end{array}$ & $\begin{array}{l}0 \\
\text { के } \\
\text { के }\end{array}$ & $\begin{array}{l}0 \\
\dot{q}\end{array}$ & m \\
\hline 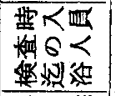 & ৪ 㝵 \& & $\stackrel{\mathscr{్}}{\mathfrak{N}}$ & \& & 今ึ & ళ్లి & เั๋ & $\begin{array}{l}\stackrel{\infty}{\mathfrak{g}} \\
\stackrel{n}{2}\end{array}$ \\
\hline 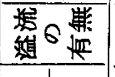 & $\begin{array}{lll}1 & 1 & \text { 量 } \\
\end{array}$ & & & & & & \\
\hline 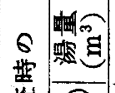 & 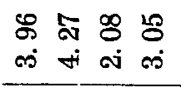 & E & $\begin{array}{l}\text { P } \\
\text { o }\end{array}$ & $\underset{\infty}{\mathfrak{s}}$ & 5 & $\begin{array}{l}\text { P } \\
\text { ง่ }\end{array}$ & E \\
\hline \begin{tabular}{l|l} 
畑 \\
㤩 \\
\end{tabular} & 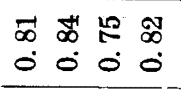 & $\begin{array}{l}\text { ป } \\
\text { - }\end{array}$ & $\begin{array}{l}8 \\
0 \\
\end{array}$ & $\begin{array}{l}\mathscr{8} \\
0 \\
\end{array}$ & जi & $\begin{array}{l}8 \\
0 \\
\end{array}$ & $\begin{array}{l}\not \\
0 \\
0\end{array}$ \\
\hline 急 & $\begin{array}{llll}2 & 8 & 1 & 1 \\
\infty & 8 & 0 \\
0 & 0 & 0 & 0 \\
\end{array}$ & $\stackrel{-}{-}$ & $\begin{array}{l}\infty \\
0 \\
0\end{array}$ & $\begin{array}{l}\text { ठ } \\
0 \\
\end{array}$ & $\begin{array}{r}-4 \\
-i \\
\end{array}$ & $\begin{array}{l}\infty \\
0 \\
0\end{array}$ & $\begin{array}{l}H \\
0 \\
0\end{array}$ \\
\hline 吙 氖 & 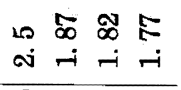 & $\begin{array}{l}\text { ำล } \\
\text { งส่ง }\end{array}$ & 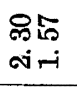 & 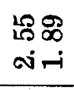 & 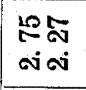 & 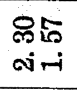 & $\begin{array}{l}10 \% \\
100 \\
\text { iv-i }\end{array}$ \\
\hline 恋 & 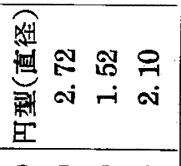 & 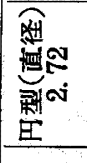 & 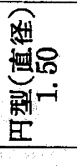 & 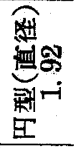 & 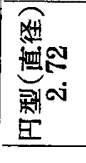 & 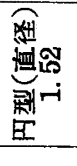 & 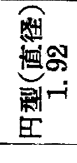 \\
\hline 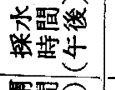 & 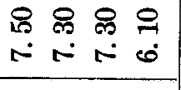 & & & & & & \\
\hline 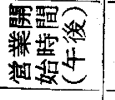 & $\begin{array}{llll}8 & 8 & 8 & 8 \\
\infty & \text { का } & \text { of } \\
\end{array}$ & & & & & & \\
\hline 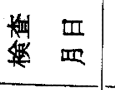 & 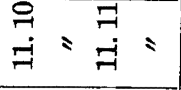 & & & & & & \\
\hline 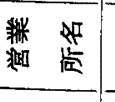 & 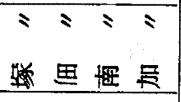 & $\begin{array}{l}\text { 姫 } \\
\text { 㟓 }\end{array}$ & $\begin{array}{l}\text { 出 } \\
\text { 睎 }\end{array}$ & $\begin{array}{l}\text { 霖 } \\
4\end{array}$ & $\begin{array}{l}\text { 岖洍 } \\
\text { 琋 }\end{array}$ & 糔 & 事 \\
\hline $\begin{array}{l}\text { 踝 } \\
\text { 监 }\end{array}$ & 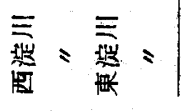 & 略 & & 蹗 & $M$ & & 哭 \\
\hline
\end{tabular}

（2）湯の深さ，湯の量，溢流の有無.

湯の深さは男女共最高 $1.1 \mathrm{~m}$, 最低 $0.70 \mathrm{~m}$, 平 均 $0.91 \mathrm{~m}$,である. 湯の量恃男女共最高 $7.80 \mathrm{~m}^{3}$, 最低 $1.37 \mathrm{~m}^{3}$ 平均 $3.41 \sim 3.42 \mathrm{~m}^{3}$ である。溢流 しているものは男湯82件の内 42 件，女湯 22 件のう ち11件である.

（3）採水時までの入浴人員

男湯の入浴者数最高 325 人, 最低 48 人, 平均 152 人, 女湯の最高 300 人, 最低 54 人, 平均 158 人である.

（4）浴水の細菌学的並び飞理化学的性状 調査成績を第2表に示した。

\begin{tabular}{|c|c|c|}
\hline 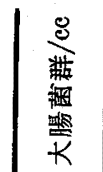 & 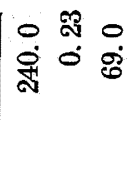 & 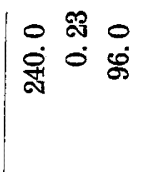 \\
\hline 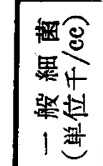 & 离 & 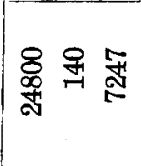 \\
\hline 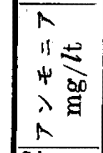 & 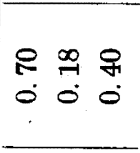 & $\mid$\begin{tabular}{lll}
8 & กิ \\
0 & \multirow{1}{*}{} & 0
\end{tabular} \\
\hline 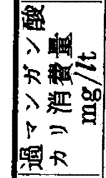 & 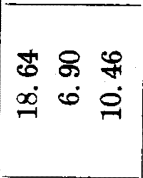 & 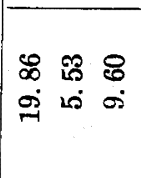 \\
\hline 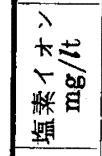 & 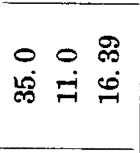 & 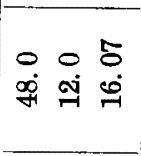 \\
\hline 喓 & $\begin{array}{lll}0 & 0 & \sim \\
\kappa & 0 & 0\end{array}$ & $\begin{array}{lll}+ & 0 \\
\leftarrow & 0 & 0\end{array}$ \\
\hline 龂 & 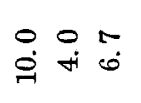 & $\begin{array}{lll}0 & 0 & -1 \\
0 & + & +\end{array}$ \\
\hline 照 & $\begin{array}{lll}0 & 10 \\
0 & 0 & 0 \\
= & 0 & 0\end{array}$ & \begin{tabular}{lll}
0 & 0 & 0 \\
\multirow{H}{*}{} & L & 0
\end{tabular} \\
\hline 哭 & $\begin{array}{lll}0 & 0 & \infty \\
\dot{f} & \dot{+} & \Re \\
\dot{f}\end{array}$ & $\begin{array}{l}0 \\
\dot{H}\end{array}$ \\
\hline & 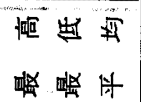 & 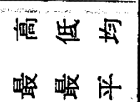 \\
\hline & 颀 贸 & W 罡 \\
\hline
\end{tabular}




\section{3. 考察}

污水の污染㤎限量は未だきまつていないので，その点 Кついては将来炑ゆずる．ただし一般細菌数が $1 \mathrm{cc}$ 中 K100万を越えるものが多いととは注意を要する.

ここには若干の項目について, 男湯と女湯, あるいは 一般公监浴場と市営公衆浴場の比較をする。

濁度, 色度, 過マンガン酸カリ消費量飞ついて, 男女 別平均值の差の検定は第 3 表に示した.

第 3 表 男女別平均値の差の検定

\begin{tabular}{l}
\hline \\
\hline
\end{tabular}

一般公衆浴場, 市営公衆浴場共飞男湯の濁度は女湯の 濁度より大であり，その差有意である.

一般公采浴場の男湯の色度は女湯の色度より大であり， その差は有意であつた。

一般市営公衆浴場の男湯相互, 女湯相互の平均值の差 の検定を第 4 表に示した。結果はいずれも有意の差はな い.

第 4 表一般公臬浴場 市営公衆浴場の差の検定

\begin{tabular}{|c|c|c|c|c|}
\hline & \multicolumn{2}{|l|}{ 濁 } & \multicolumn{2}{|c|}{$\begin{array}{l}\text { 過マンガン酸 } \\
\text { カリ消費量 }\end{array}$} \\
\hline & 男湯 & 女湯 & 男 湯 & 女湯 \\
\hline 市営浴場平均 $M=17$ & 9.9 & 7.6 & 10.40 & 9.3 \\
\hline 一般浴場平均 $\mathrm{N}=82$ & 8.7 & 7.7 & 11.30 & 10.80 \\
\hline 差（市営一般） & 1.2 & 0.1 & -0.90 & -1.50 \\
\hline 差 の 検 & なし & なし & なし & なし \\
\hline
\end{tabular}

一般, 市営の各々について谷水の溢流の有無の平均值 の差の検定を第 5 表に示した，結果はいずれる有意の差 はない。
第 $\mathbf{5}$ 表 溢流の有無別平均值の差の検定

\begin{tabular}{|c|c|c|c|c|}
\hline & & 濁度 & 色度 & $\begin{array}{l}\text { 過マンガン酸 } \\
\text { カリ消費量 }\end{array}$ \\
\hline \multirow{4}{*}{$\begin{array}{l}\text { 般 } \\
\text { 公 } \\
\text { 衆 } \\
\text { 浴 }\end{array}$} & \multirow{3}{*}{$\begin{array}{l}\text { 滑流有平均 } M=82 \\
\text { " 無平均 } \mathrm{N}=81 \\
\text { 差 (無一有) }\end{array}$} & 8. 2 & 6.3 & 10.59 \\
\hline & & 8.2 & 6.4 & 11.53 \\
\hline & & 0 & 0.1 & 0.94 \\
\hline & 差 の 検 定 & I & なし & なし \\
\hline 市 & 溢流有平均 $M=22$ & 8.3 & 6.3 & 9.41 \\
\hline 公 & " 無平均 $\mathrm{N}=17$ & 9.6 & 6.3 & 10.65 \\
\hline 瞹 & 差（無一有） & 1.3 & 0.0 & 1.24 \\
\hline 場 & 差 の 検 & なし & なし & なし \\
\hline
\end{tabular}

\section{IV 総括並びに結論}

昭和28年9月21日〜10月20日まで1 カ月間にわたり, 大阪市内公衆浴場82件, 昭和28年11月 4 日 11日烦大阪 市営公垗浴場22件について浴水の細菌学的並びに理化学 的調查を行つた.

\section{1 一般公监浴場}

男湯の平均以濁度 8.7 , 色度 6.6 , 反応 6.6 , 塩素1オ ン $16.40 \mathrm{mg} / l$, 過マンガン酸カリ消費量 $11.30 \mathrm{mg} / l$, 了 ンモニア $0.38 \mathrm{mg} / \mathrm{l}$ ，一般細菌数 389 万 $/ \mathrm{cc}$, 大腸菌群の M.P.N.20/ce である.

女湯は濁度 7.7, 色度 6.1 でいずれも男湯のそれより 低くその差は推計学的に有意である.

その他の項目については，男湯のそれとの間に有意な 差はない.

\section{2 市営公衆浴場}

男湯の平均は濁度 9.8 , 色度 6.7 , 反応 6.7 , 塩素1才 ン $16.39 \mathrm{mg} / l$, 過マンガン酸カリ消費量 $10.46 \mathrm{mg} / l$, 了

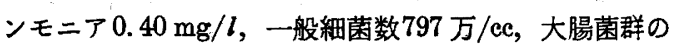
M.P.N. 69/ec である.

女湯の平均は濁度 7.9 で，男湯のそれより低く，その 差は推計学的に有意である. 其他の項目については男湯 のそれとの間飞有意の差はない。

3 其 他

一般と市営の男湯相互, 女湯相互の間飞峈各項目につ いて有意の差はない，浴水の溢流々溢流しないすのとの 間飞は一般，市営いずれの場合にも各項目について有意 の差がない.

\section{結論}

浴水の污染の恕限量は未だ定まつていないが，今回の 調查に上れば, 一般, 市営, 男女いずれる一般細菌数が 100 万/cc を越えるむのが多く，一般浴水の改善の必 
要がある。

其他各試験項目の平均値よりみて著しく測定値の高い あのについては浴槽の清掃並びス湯の供給の完備を促す べきである.

尚浴水の溢流の有無のみを以つて浴場管理の良否は直 ちには判定出来ない.

擱筆に当り，終始御想篤なる御指導，御䩒趋を賜つた 閶西医大東田教授，京大庄司教授に詇んで御礼申し上げ
ます，晌，この調查に当り，御協力頂いた大阪市衛生局， 市保健所並びに衛生研究所各位に対し深謝の意を表しま 寸.

参文献

1) 原田，岡本: 国民衛生. 1, (11), 30, (1924).

2) 鬼木: 同誌. $8,82,(1931)$.

3）宝意：公衆衛生誌。 $3,11,(1947)$.

4) 豊川外 9 名 : 同誌. $5,41,(1949)$.

5) 大園, 阪本 : 京都医大雑誌。 $46,(4), 239,(1950)$.

\title{
Sanitary Investigations on the Water Qualities of Pubic Baths
}

\section{(Rep. 1) On the Examinations of Water Qualities of Public Baths in Osaka City}

\author{
Shigeru Sakamoto \& Masao Kotake \\ Osaka Municipal Hygienic Laboratory
}

The bacteriological and physico-chemical examinations of the water qualities of 104 public baths were carried out in Osaka City, 1953.

The following results were obtained.

The numbers of general bacteria in lc.c. of bath water were greater than $10^{6}$ in almost cases.

From this experimental results, the need for cleaning of bathtab, sufficient supply of fresh water are urgent necessity. 


\title{
公衆浴場水の衛生学的研 究
}

第 2 報 浴場水質の時間的変化

\author{
大阪市立衛生研究所 \\ 阪本茂。小竹正雄。宇野源太
}

\section{I 緒言}

昭和29年 1 月 22 日以降，生野区管内性公衆浴場 80 件 あつて，その内，浴場組合加入浴場77件，非加入浴場 3 件で，ての非加入浴場が浴場料金値上げに反対したため, 組合加人浴場は休業し, 非加人浴場 3 件のみが開業して いた. 3 件の浴場水の污染状况を知らんがため 1 月 26 日, 27日の両日にわたり，浴水の細菌学的並びと理化学的試 験の調査を実施したので，その成績の概要を報告する.

\section{II 検查材料並びに検査方法}

検査期日：昭和29年1月26日，同1月27日

使 用 水: 大阪市水道水

検査試料 : 男女浴槽浴水，浴槽中央部深さ約 $30 \mathrm{~cm}$ のと ころを採酌した。

検查項目

理化学的検査 : 水温, 濁度, 色度, PH. アンモ二ア 性窒素, 塩素イオン, 過マンガン酸カリ消費量 細菌学的検查 : 一般細菌集落数 $(1 \mathrm{cc})$. 大腸菌群最確 数 (M.P.N)

検査回数 : 新生野温泉 26 日, 27 日の両日の午後 3 回, 銀 水，出世湯は26日午後 4 時， 8 時の 2 回にわたり採水, 検査は直ちに行つた。

尚，試験方法怯厚生省领料水衛生指針水質試験方法飞 拠つた。

\section{III 検查成績並びに考察}

検査成績は第 1 表の通りである.

第 1 表の検査成績より観察すると

1 澄流の有無……溢流飞なつている状態は甚だ少なか つた.

2 入浴人員数……男湯より女湯の方が素が多く，時 間別次任午後 8 時が最も多い。

3 濁度, 色度……般飞入浴の增加, 時間の経過を追 つて濑次その值の增加を示すか，減少の傾向を示して
いる時むある．男湯は女湯より大きい值を示している。 4 PH. ..............時間の経過と共飞僅か飞酸性飞傾く.

5 アンモニア性窒奖, 塩素イオン, 過マンガン酸カリ 消費量……以上 3 者はいずれも時間の経過と共供大

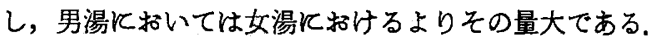
6 一般細菌数，大腸菌群……両者共飞その数を堌大す るが，時飞減少の傾向を見ることがある，ただし溢流 時は細菌数の少ないのは注目すべきである.

以上の成績と昭和 28 年秋の公䍃浴場82件の浴水水質の 平均値（第 1 報）とを比較すると，生野新温泉の 26 日恃 高い値を示し，一般細菌数のみ低い值を示している. 27 日は各項目共公监浴場の平均值飞近く, 特飞細菌数は低 い值を示し，26日に比してやや良い結果を示している.

銀水湯，出世湯は入浴者が少ないにもかかわらず，生 野新温泉の 27 日より悪い結果を示しているが，一般細菌 数は, 最高 640 万を示している.

以上要するに浴水の污染度は男湯, 女湯いずれむ時間 の経過と共に漸次増加する. 入浴者数は男湯より女湯の 方が大であるにかかわらず，男湯は女湯より污染度大で ある．とれは女湯の方が男湯より多くの浴水を消費する ので, 新鮮浴水の補充がより大なること, 浴槽外飞ての 身体洗滌が女の方により徹底していること，また労微の 差等が指摘される.

昭和24年飞大園, 阪本は公衆浴場水の衛生学的検査を 行つたが, 浴水の污染度は入浴者数の増加と共飞増加し, 19〜21時飞最高飞達し，終業前の 2 時間に招いては浴客 の減少と共飞污染度は低下し来る。 また性別飞みると男 湯は女湯より污染度が大である1。

昭和 24 年飞豐川等も公衆浴場の浴水污染飞ついて報し， ある時間が経過すると減少の傾向を示したという2). 昭和22年飞宝意は細菌学的見地より米子市の銭湯は著 しく污染していると報しているが，米子市では浴水とし て井戸水を用いて怙り，浴槽の渄い方が不充分なためか， 入浴前すでと最低約 23 万個の細菌を $1 \mathrm{ce}$ 中に認めたと (いう3). 


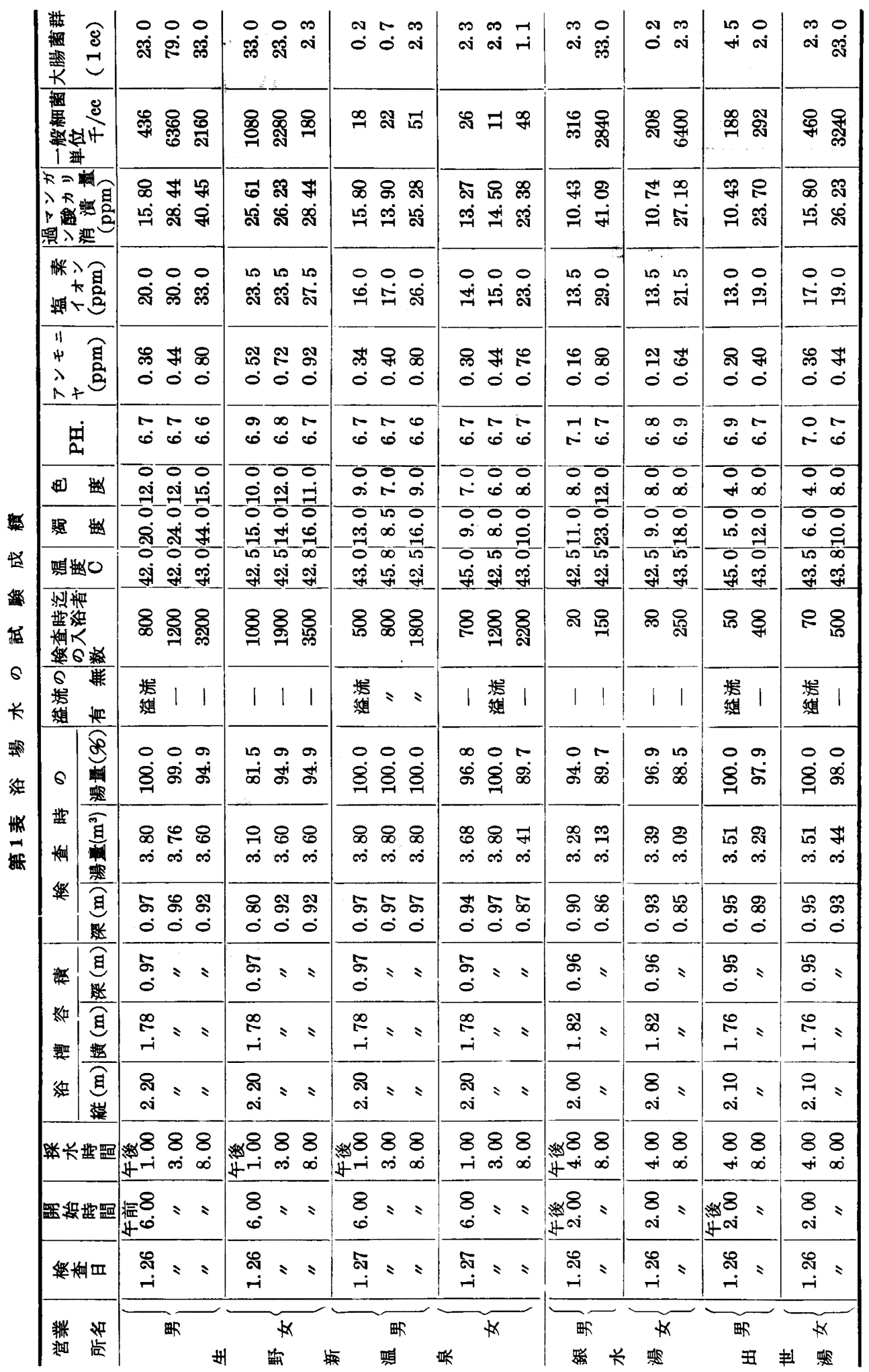


大正13年原田，岡本が污染度の最も著しいいわゆる䆩 民地帯の浴水についで)。昭和 6 年鬼木は公采浴場の浴 水について調査したがうその成績は次の通りである.

第 2 表 大正13年調查成績（貧民地）

\begin{tabular}{|c|c|c|c|c|c|c|c|}
\hline & \multicolumn{2}{|c|}{ 男湯 } & \multirow{2}{*}{$\frac{\text { 女 }}{\text { 午前 }}$} & 湯 \\
\hline & & & & 午前 & 午後 & & 午後 \\
\hline 塩 & 素 & 1 & $\pi$ & 14.8 & 29.2 & 17.7 & 27.8 \\
\hline$T$ & ข & $\mp$ & $=$ & 2.06 & 3.9 & 1.92 & 4.40 \\
\hline & 当性 & 7 & $E=7$ & 1.44 & 3.00 & 1. 31 & 3.02 \\
\hline 過 & ンカ & 酸 & 山消費量 & 11.8 & 31.0 & 14.1 & 37.5 \\
\hline 固 & 形 & 物 & 粉 量 & 109.0 & 128.0 & 102.0 & 140.0 \\
\hline 細 & 菌 & 数 & $\left(37^{\circ} \mathrm{C}\right)$ & 14600 & 31100 & 14570 & 23030 \\
\hline
\end{tabular}

第 3 表 昭和 6 年調查成績（公衅浴場）

\begin{tabular}{|c|c|c|c|c|c|c|}
\hline & & & \multicolumn{2}{|c|}{ 男湯 } & \multicolumn{2}{|c|}{ 女 湯 } \\
\hline & & & 11時 & 22時 & 11時 & 22時 \\
\hline 塩 & 萎 & $1 オ$ オ & 8.8 & 13.0 & 9.1 & 14.0 \\
\hline 7 & ข & $E=7$ & 0.14 & 0.30 & 0.14 & 0.31 \\
\hline 蛋 & 白 性 & フンモ & 0.31 & 0.60 & 0.28 & 0.70 \\
\hline 過 & ンカ & 醊カリ消費量 & 7.17 & 18.65 & 7.45 & 22.46 \\
\hline 固 & 形 & 物 棇 量 & 70.0 & 91.0 & 71.0 & 197.0 \\
\hline 細 & 菌 & 数 $\quad\left(37^{\circ} \mathrm{C}\right)$ & 11239 & 32860 & 11160 & 51350 \\
\hline
\end{tabular}

昭和24年の污染度大の原因は戦前に比し，人口の割合 に浴場数の少なからたてと並びに燃料事情の悪化による 使用水量の減少飞基く.

今回の成綪からみて注目すべきことは湯盈 100 \%6の溘 流状態の時は外観もやや良好で細菌が甚だ少ないことで ある. 満水状態としておくことが公衆衛生上の急務であ
る. 其の他個人の浴場使用態度の衛生的なるととを要す るのはもちろんである.

$$
\text { IV 結論 }
$$

大阪市生野区管内公衆浴場の内, 組合非加入浴場 3 件 飞つき昭和29年 1 月 26 日，27日にわたり，浴場水水質の 時間的変化を調査した.

採水時間は生野新温泉は26. 27日共13時, 15時, 20時 の 3 回で, 他の 2 件は16時, 20時の 2 回である.

その成績より得た結論は次の通りである.

1 入浴人員数の最む多いのは男女湯共 17 時より 21 時で ある。

2 浴水の濁度, 色度, アンモニア性窒素, 塩素イオン, 過マンガン酸カリ消費量, 細菌数等を綜合した污染度 は時間の経過と共に, 入浴者数の増加飞比例して増大 する.

3 浴場の使用水量の不充分等の悪条件の改善が浴水清 浄化の条件となる.さらに業者の終業後に抽ける浴槽 洗榇の徹底が大切である。

終りに臨み，御愁切なる御指導と御校閲を賜わった関 西医大東田教授，京大庄司教授倿心上り厚く御礼申し 上げます。

佾御協力いただいた大阪市衛生局，保健所，衛生研究 所の各位に深謝いたします。

\section{参考 文 献}

1）大闎，阪本: 京都医大雑誌。 46 (4), 239, (1950).

2）辢川外 9 名: 公衆衛生誌. $5,41,(1949)$.

3）宝意：公衆衛生誌。3,11，(1947).

4) 原田, 岡本: 国民衛生. 1 (11), 30，(1924).

5) 鬼木：同誌。 $8,82,(1931)$. 


\title{
Sanitary Investigations on the Water Qualities of Pubic Baths
}

\author{
(Rep. 2) Time Sequenital Investigations of the Water \\ Qualities of Public Baths
}

Shigeru Sakamoto, Masao Kotake \& Genta Uno

Osaka Municipal Hygienic Laboratory

The water qualities of three public baths in Ikuno District of Osaka City were investigated two or three times a day, January 1954,

The following results were obtained.

Owing to insufficent water supply, the pollution of the bath water increased with time, namely, in proportion to the total cumulative number of bathers.

Therefore, sufficient water supply and thorough washing of bathtub should be required. 